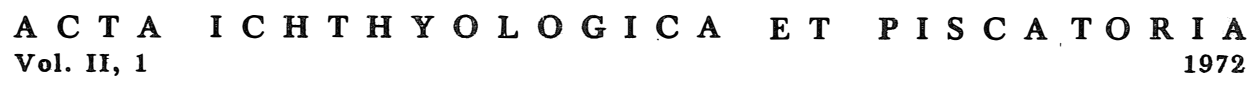

Tadeusz KAWKA

Technology

\title{
GEOMETRY OF CIRCULAR CUTTER AND ITS INFLUENCE ON SPECIFIC CUTTING FORCE OF FISH RAW MATERIAL
}

\section{WPEYW GEOMETRII OSTRZA NOZA TARCZOWEGO NA WARTOŚC JEDNOSTKOWEJ SIEY KROJENIA SUROWCA RYBNEGO}

\author{
From Institute for Exploitation of Sea $\mathbb{R}$ esources \\ Presented, are the results of analysis relating to geome- \\ try of circular cutter and its influence on specific cutting \\ force. Based on these analysis, are practical conclusions \\ drawn for selection of circular cutters to be applied in \\ mechanical cutting of fish.
}

\section{INTRODUCTION}

The performed studies permitted to ascertain that specific cutting force of fish raw material depends on kinematic parameters of process ( $\mathrm{K} \mathrm{a} \mathrm{w} \mathrm{ka}$, 1972). It may be assumed that, speed of tool and speed of material feeding are not the only factors influencing such force. Previous experiments support the hypothesis that, specific cutting force and the quality of cutting, depend on geometry of cutting tool blade ${ }^{x}$.

On problem of organic materials cutting hadworked Stroppe l (1953), Z i l i n (1963) and others. In spite of different investigation method, the obtained results for selected group of materials may be considered as concurrent and allow for relative conclusions. No complexinvestigations had been performed for all raw materials. Particularly little works exist on cutting of fish raw material.

From point of view of cutting mechanics, the fish raw material is very specific: Many particular characteristics, such as chemical, biological and physical, which change in time and depend on species and size of fish, make difficult any uniform determination. Difficulties in quantitative determination of some basic characteristics point to shortage of theoretical analysis in investigations performed. A d a m k e w i c z and $\mathrm{Hempel}$ (1967), having analysed the mechanical properties of fish meat, specified that: "The only way to determine the actual resistance in cutting is to experiment". Such assertion proves justified for the present stage of knowledge on physical processes, which are taking place during mechanical division of fish body.

Method applied for presented investigations had been developed on works of Gu r e,vi c (1966) who attempted to unify the definitions relating to fish

$\overline{x)}$ Geometry of circular cutter blade - tool contour of angles. 
cutting processes and worked-out the basis of mechanics for performance of circular cutters. A common method applied in studies and uniformity of definitions, is very essential for comparisons. The assumptions and basic definitions of cutting process, must be precisely defined.

In operation of circular cutters, definition of cutting process means mechanical division of body by a tool of wedge-shaped blade which acts on material through cutting microelements situated at its periphery. Such microelements are of feather-edge shape and originate during the tool sharpening on abrasive material. Cutting properties of blade depend, thus, on type of microelements resultant from sharpening method, geometry of blade, grade of steel and its technological processing and from grade of abrasive material.

Cutting process is taking place due to cutting force which acts in relation: blade - material and results in division of cell.

Cutting force is not reflecting the resistance offered by material. Active in material division are, also, bothside surfaces of blade, which may accelerate or slow down the process of cutting according to properties of material. For plastico-adhesive materials the action of cutting is slowed-down and may considerably increase the value of cutting resistance. Beyond cutting force, value of such resistance is influenced by friction and adhesion forces which occure between the material and both active sides of tool, and by deformation of material.

Concluding from the above, smallest angle of blade should be used to avoid excessive plastic deformation of cut material. Considering durability of blade, the angle can not be minimized below certain limits mainly determined by the properties of material in cutting and by material of tool.

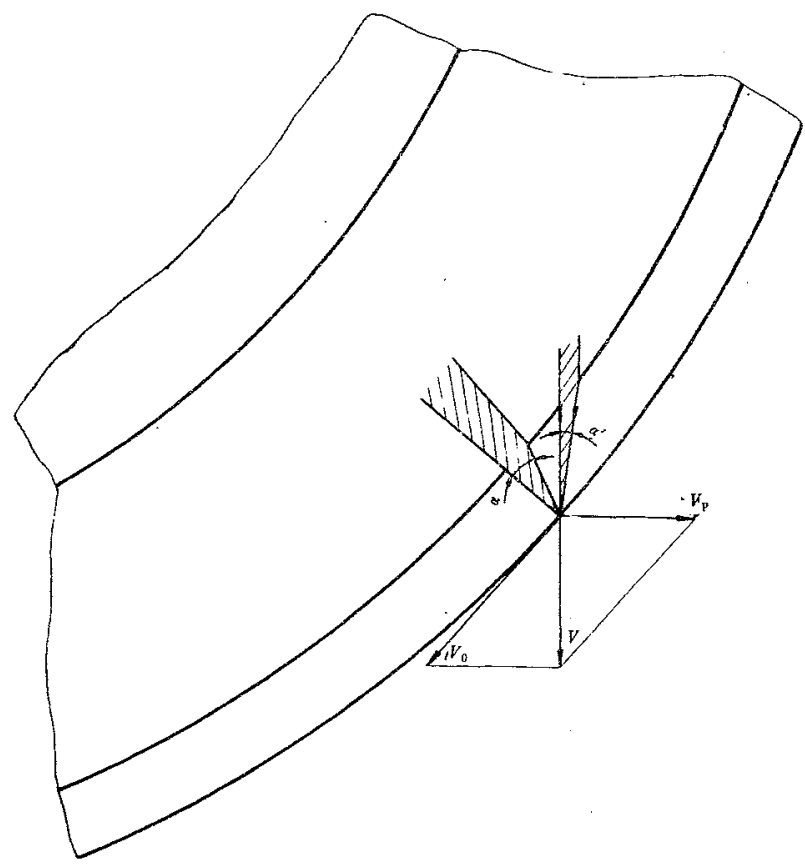

Fig.1. Apparent change of blade angle value of circular cutter 
When cutting with circular cutter peripherial speed of cutter - $v_{0}$ varies distinctly to speed of material feed $-v_{p}$, and the blade works with apparently decreased angle - $\alpha$ ( $G$ u r e vi c, 1966). Such decrease results from inclination of blade wedge plane at cutting moment in relation to change of os cillation in direction of cutting speed - $v$ from direction of peripherial speed - $v_{0}$ (Fit.1).

Increasing ratio of peripherial speed to speed of material feeding decreases the surface of blade microelements contacting with cut material and results in decrease of cutting force. The relationship of friction and deformation of material at cutting wedge surface will also change and consequently lead to decrease of cutting resistance.

\section{METHOD}

The test were carried-out on specially-built stand. Detailed description of this stand and of recording and measuring instruments was presented in work of K a w k a (1972). Used, were medium size fishes of the following species: cod - Gadus morrhua L., hake - Merluccius merluccius (L.), Norway haddock - Sebastes marinus (L.) and mackerel - Scomber scombrus. (L.).

Kinematic parameters of cutting processes were not varying and were maintened within the limits of highest parameters worked-out in previous investigations ( $\mathrm{K} \mathrm{a} \mathrm{w} \mathrm{k} \mathrm{a,} \mathrm{1972).} \mathrm{Peripherial} \mathrm{speed} \mathrm{of} \mathrm{cutting} \mathrm{edge} \mathrm{amounted}$ to $20 \mathrm{~m} / \mathrm{s}$ and the speed of fish feeding against cutter $-0.7 \mathrm{~m} / \mathrm{s}$.

The cutting was performed with cutters of plain and sector-profiled blade. The profiled blade was of sector-shape with not very deep incuts evenly spaced on circumference (Fig.2). The included angles amounted to 8, 10, 15, 20,25 and $30^{\circ}$. The cutters were sharpened by one side grinding. For comparison, applied also the cutters grinded on both sides. All cutters were of uniform thickness and of inclination angle $6^{\circ}$.

Applied during the experiments were the beheading cuttings in plane determined by technological requirements. The cutting was started from dorsal side of fish which was laying in feeding holder perpendicularly to circle of cutter.

A waterspray on cutter and fish was applied during the cutting. Construction of fish holder prevented any jamming of fish on cutter. Such condition had to be ensured to permit the use of definition of cutting force; an error entered into the results may be considered as negligeable.

The results obtained had to be calculated into the searched qualities (see mathematical formulas in work of $\mathrm{K} \mathrm{a} \mathrm{w} \mathrm{k} \mathrm{a,} \mathrm{1972).} \mathrm{Calculated} \mathrm{absolute}$ values relating to particular measurements were brought to mean values for each serie of measurements. Specific values were estimated with confidence interval of 0.90 . 

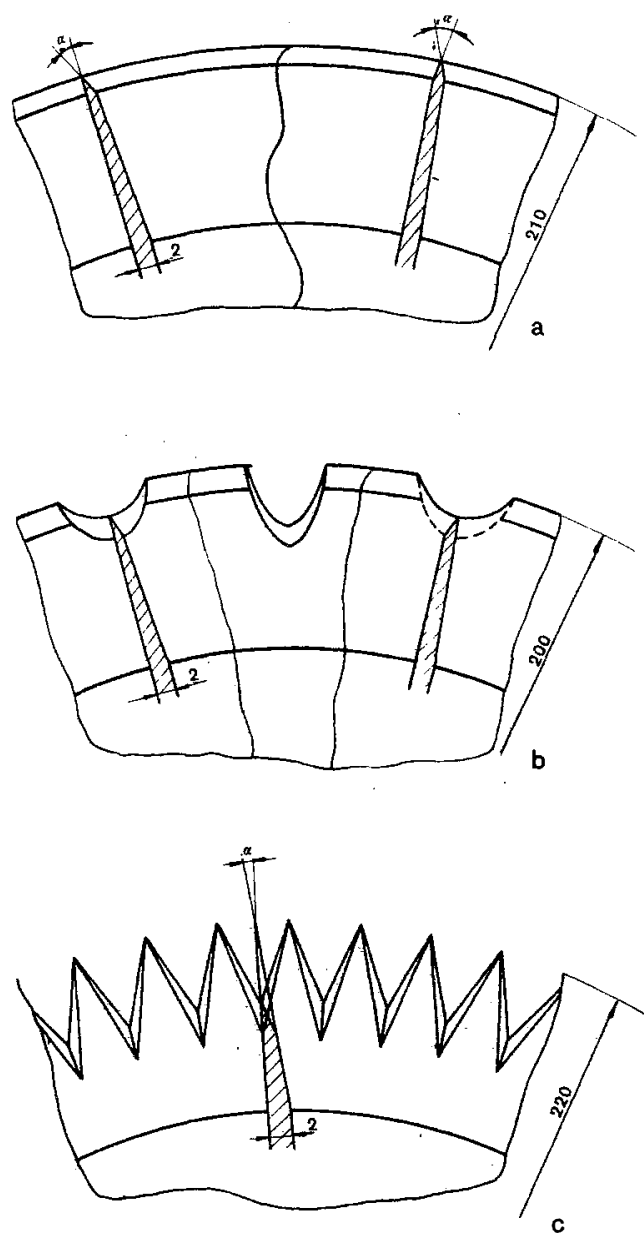

Fig.2. Patterns of circular cutter blades used during investigations: a. - plain blade, b - sector-profiled blade with oval clit-outs, c - profiled blade - teeth shaped

\section{RESULTS}

The results obtained permitted to study the investigated relationships. This is presented graphically in rectangular arrangement of coordinates, with angle of blade $\alpha$ assumed as variable independent.

Fig. 3 presents the relationship of cutting force to blade angle elaborated for beheading of fresh and frozen fish in application of plain and sectorprofiled blades. Experimental data plotted on diagram and obtained the arrangement of points near to straight line. It means that the relation may be described as linear function. For determination of coefficients applied the 


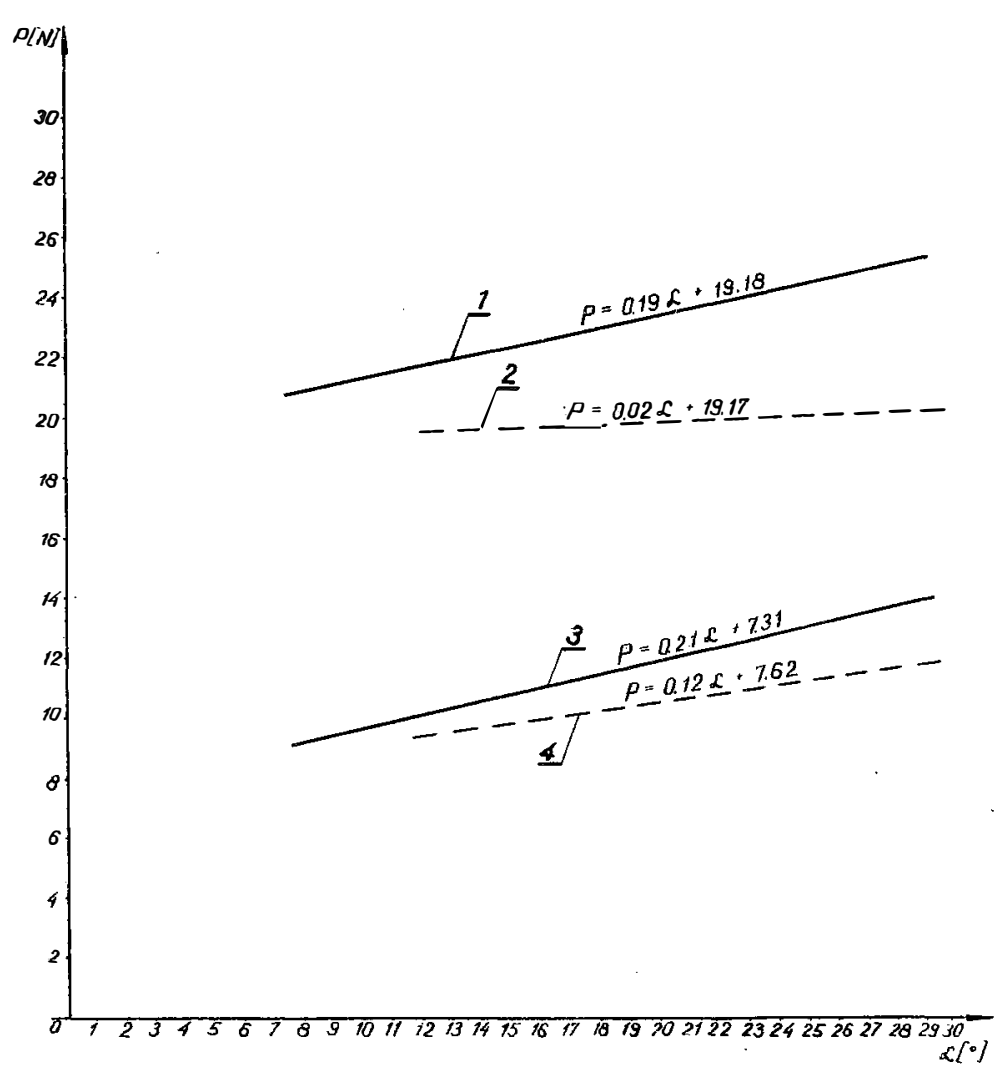

Fig.3. Regression lines presenting the relationship of cutting force to blade ałgle, made for cods of medium sizes: lines 1 and 3 relate to fresh fish,lines 2 and 4 relate to defrozen fish

least squares method; nominated direct equations are as follows:

- for cutters of plain blade, $\mathrm{P}=0.19 \alpha+19.18$ for fresh fish cutting and $P=0.02 \alpha+7.31$ for cutting of frozen fish;

- for cutters of sector-profiled blade, $P=0.21 \alpha+19.17$ for fresh fish cutting and $P=0.12 \alpha+7.62$ for frozen fish cutting.

All regression lines indicate positive correlation, what means that, an increase of blade angle $\alpha$ corresponds to increase of cutting force P. Directional coefficient of straights varies for each nominated equation. Its value is higher for cutters of plain blade than for cutters of sector-profiled blade. It may also be ascertained that either for fresh or defrozen fish, cutting force of plain-blade cutter is higher than cutting force of sector-profiled cutters.

Additional tests were performed for sector-profiled cutters of various shape (Fig.2). In all tests, the obtained results of cutting force were lower than for cutters of plain blade. Similiar results were also obtained for cut ters of teeth-shaped blade. The quality of cutting was distinctly decreased. An attempt to increase the cutting speed gave no positive results 
The hypothesis may be concluded that cutting blades shaped as regular incuts permit to obtain smaller value of cutting force than the cutters with plain blade. The shape, quantity and depth of incuts influence the quality of cutting.

Comparative tests were performed for cutters ground on one side and on both sides. The values of cutting force obtained for cutters ground on both sides were by $10 \%$ lower. This should be explained by different grade of cutting microelements produced during blade grinding.

Distribution of cutting force along cutting line is presented on Fig.4. Diagram was prepared for beheading of defrozen hake with sector-profiled blate

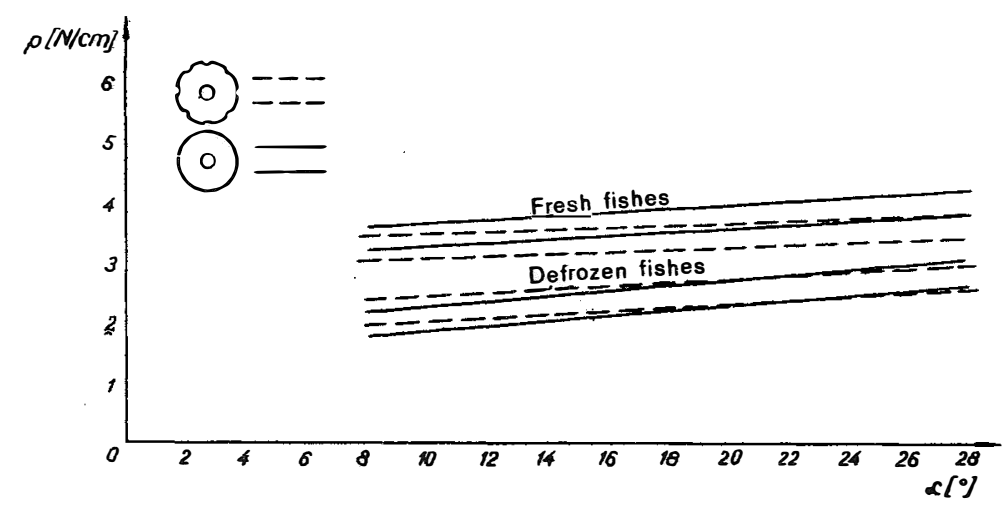

Fig. 4. Distribution of cutting force along cutting line

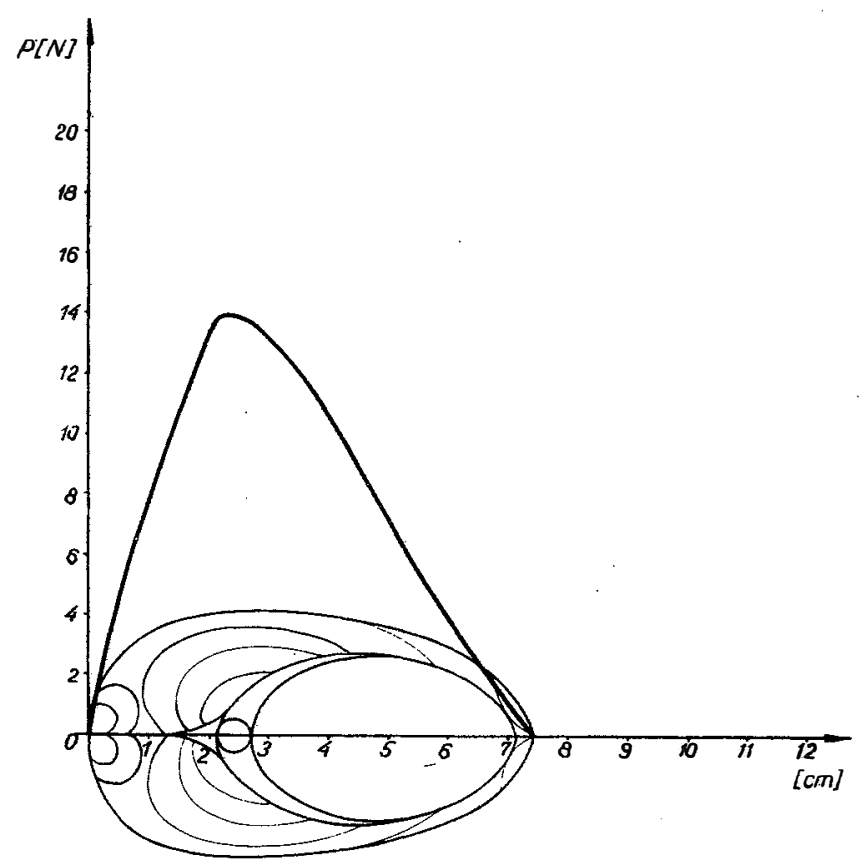

Fig.5. Relationship of specific cutting force to blade angle 
Fig. 5 presents the relationship of specific cutting force from cutting angle of sector-profiled and plain blade cutters. The relationships are rectilinear and an estimation had to be elaborated. The mean deviation of regression was determined and the interval confidence for straights was drawn.

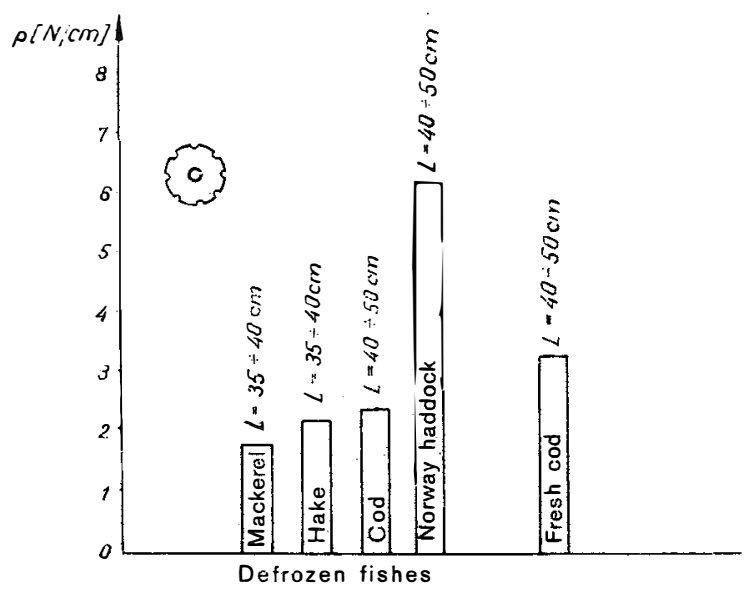

Fig.6. Histogram of specific cutting force for various species of fish

On histogram (Fig.6), are compared the specific cutting forces in relation to various species of fish. Distinctly higher values $p$ obtained for Norway haddock should be explained by higher cutting resistance which presented the skin covered with ctenoidal scale. The cod species and mackerels are covered with cycloidal, thin and delicate scale. Depends on species on fish, the variations in specific cutting force may be large. Basing on biological

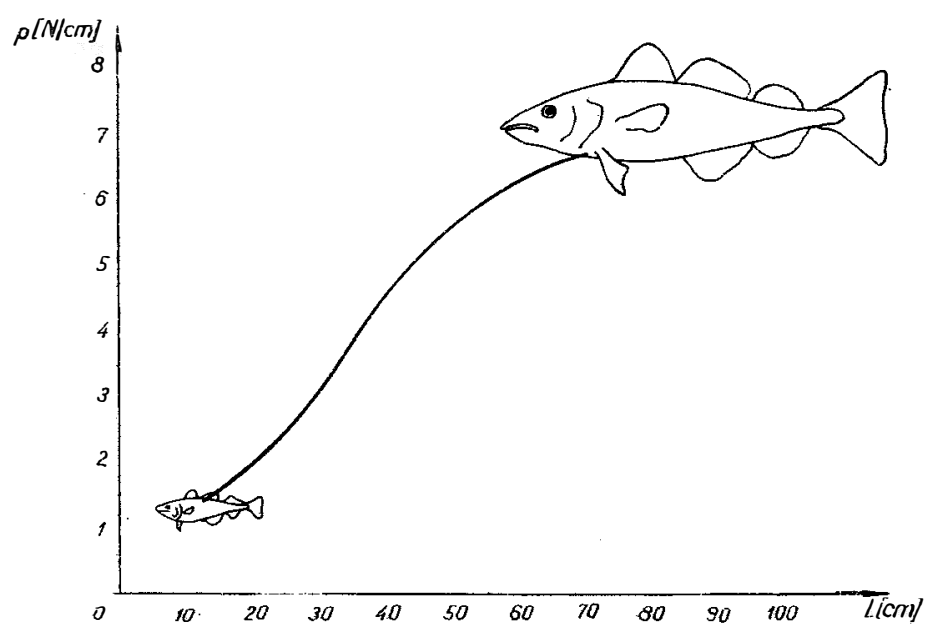

Fig.7. Relationship of specific cutting force to fish sizes.

Diagram made for fresh cod 
characteristics, the specific cutting force for mackerel and Norway haddock may be assumed as limit values for fish species which are important in fishery.

Presented on Fig. 7 are the interrelations of specific cutting force to size of fish. Diagram relates to beheading performed with cutter of sector-profiled blade. Basing on the obtained correlative curve, it may be assumed that specific value of cutting force depends on size of fish (beyond previously determined relationships of species and quality). Such ascertion conditions the comparison of results expressed as "p" qualities.

\section{CONCLUSIONS}

The value of blade angle has an influence on the specific cutting force. This relationship is of linear nature. The lowest values of specific cutting force were obtained at the lowest values of angle. No influence of varying in blade angle values was noted on quality of cutting.

A cutter ground on both sides allows to decrease the cutting force by about $10 \%$ in comparison to value of cutting force effected by oneside ground cutter.

Considering the strength and endurability of tool, the angle of blade should be not below $10-15^{\circ}$. Excessively small angle of blade causes its early blunting. However, the deciding factor in this respect is the technological processing of tool.

Quality of cutting blade influences the value of cutting force and is of certain importance in relation to quality of cutting. The cutters of sector-profiled blade with small oval cut-outs evenly spaced on circumference, proved lower values of cutting force (by about $15 \%$ ) in comparison to cutters of plain blade (regardless to species and condition of fish). Cutting quality for this type of cutter is good at cutting speed ranging between $15-24 \mathrm{~m} / \mathrm{s}$ in relation to species and condition of fish . $\mathrm{K} \mathrm{a} \mathrm{w} \mathrm{k} \mathrm{a,} \mathrm{1972).}$

The value of cutting force depends on the species, condition and size of fish. This relates also to specific cutting force, which may be changing distinctly in relation to species. For exemple, specific cutting force for Norway haddock is three times higher than for mackerel. Forfresh fish, the value of specific cutting force is higher than for defrozen fish.

Summarizing the conclusions basef on performed investigations and tests, it may be ascertained that for mechanical processing of fish, the blade of circular cutter should be profiled as small oval cut-outs evenly spaced on circumference. Practically, for materials presentlyused, the value of blade angle should be about $20^{\circ}$ and the blade should be ground on both sides.

\section{REFERENCES}

A d a m ki e wi c z W., H e m p e l L.: Analiza oporów cięcia ryb. [Analysis of resistance 0 in fish cutting], Zesz.nauk. Politech.Gdańskiej 1967, nr 118. Mechanika, z.10. 
Gurevic S.G.: K voprosu ob opredelenii udel'nyhusilij rezanija ryby. Rybnoe Hozjajstvo 1966, 1.

K a w k a T.: Badania nad ustaleniem optymalnych parametrów pracy noży tarczowych do mechanicznej obróbki ryb. [Analysis on determination of highest working parameters of circular cutters in mechanical processing of fish] Acta Icht.et Pisc. 2, 1.

S t r o p p e 1 Th.: Zur Systematic der Technologie des Schneidens.Grdln. d. Landtechn. Heft 5. Düsseldorf 1953.

Zili n N.I.: Obosnovanie elementov mechanizacii i avtomatizacii processov razdelki kambal. Rybnoe Hozjajstvo 1963. Nr.12.

WPEYW GEOMETRII OSTRZA NOŻA TARCZOWEGO

NA WARTOŚĆ JEDNOSTKOWEJ SİY KROJENIA SUROWCA RYBNEGO

\author{
Streszczenie
}

W pracy przedstawiono wyniki badań, które dotyczyły określenia wpływu geometrii ostrza noży tarczowych na wartość jednostkowej siły krojenia. Badania prowadzono dla operacji odgławiania niektórych gatunków rybbędacych w stanie świeżym lub rozmrożonym.

Stwierdzono, że wartość kąta ostrza ma wpływ na jednostkową siłę krojenia, a zależność ta posiada charakter liniowy. Linie regresji wyznaczone dla różnych typów ostrzy wykazują korelacjędodatnią. Niższé wartości jednostkowej siły krojenia otrzymano przy pracy nożami o profilowanym ostrzu w porównaniu do noży o gładkiej krawędzi tnącej. Stwierdzono, że rodzaj krawędzi tnącej ma duże znaczenie dla jakości krojenia.

$\mathrm{Na}$ podstawie analizy otrzymanych wyników wyciągnięto praktyczne wnioski dla doboru noży tarczowych przy mechanicznym krojeniu ryb.

\title{
ВЛИЯНИЕ ГЕОНЕТРИИ ОСТРИЯ ДИСКОВОГО НОЖА НҢ̈ ВЕЛИЧИНУ УДЕЛЬНО: СИЛЫ РЕЗКИ РЫБНОГО СЫРЬЯ
}

$$
\text { P e } 3 \text { ю } \mathrm{Me}
$$

В работе представлены результаты исследований, которые касались определения влияния геометрии острия дискового ножа на величину удельной силы резки. їсследования проводились для операции обез'главливания некоторых видов. рыб, находящихся в свожем или размороженном состолніли.

Јстановлено, что величина угла острия имеет влияние на удельную силу резки, а зависимость эта имеет линейный характер. Линии регрессии, определённые для разных типов острий, характеризуются положительной корре- 
Јия́цией. Меньшие велйины удельной силе резпи бели получены при пользовании новами с проф̆илированным острием по сравнению с ножами $c$ глағкип режущим краем. Јстановлено, что вид режущето края пиеет большое значение, для качества резки.

На основе анализа полученных результатов сделаны практиесние выводы для подбора дисковых ножей при механическої резте рыб.

Address :

Received 14.IX.1971

Dr Tadeusz Kawka

Instytut Eksploatacji

i Zasobów Morza AR

Szczecin, ul. Kazimierza Królewicza 4.

Polska - Poland 